\title{
Precarious humanity: the double in dystopian science fiction
}

André Cabral de Almeida Cardoso ${ }^{a}$

\begin{abstract}
The double is a common feature in fantastic fiction, and it plays a prominent part in the Gothic revival of the late nineteenth century. It questions the notion of a coherent identity by proposing the idea of a fragmented self that is at the same time familiar and frighteningly other. On the other hand, the double is also a way of representing the tensions of life in large urban centers. Although it is more usually associated with the fantastic, the motif of the double has spread to other fictional genres, including science fiction, a genre also concerned with the investigation of identity and the nature of the human. The aim of this article is to discuss the representation of the double in contemporary science fiction, more particularly in its dystopian mode, where the issue of identity acquires a special relevance, since dystopias focus on the troubled relation between individual and society. Works such as Greg Egan's short story "Learning to Be Me"; White Christmas, an episode from the television series Black Mirror; Kazuo Ishiguro's novel Never Let Me Go; and the film Moon, directed by Duncan Jones, will be briefly examined in order to trace the ways the figure of the double has been rearticulated in dystopian science fiction as a means to address new concerns about personal identity and the position of the individual in society.
\end{abstract}

Keywords: identity; self; double; clone; contemporary society.

Recebido em: $16 / 09 / 2018$ Aceito em: 13/11/2018

aProfessor do Departamento de Letras Estrangeiras Modernas na Universidade Federal Fluminense (UFF). E-mail: andrecac@id.uff.br 


\section{Shades of the double}

The double is an important trope in fantastic fiction, either in its most obvious manifestation as the doppelgänger, or more indirectly, in the form of ghosts, animal spirits and demonic possession. It figures prominently in Freud's discussion on the uncanny, which is still a seminal reference in theorizations of the fantastic. Indeed, Julian Wolfreys (2002, p. 14-15) argues that the question of doubling is particularly connected to the sense of the uncanny, since "in the double there is both that which is familiar enough to be disturbing and strange enough to remind us of the otherness that inhabits the self-same", actualizing the synthesis between the familiar and the strange that is at the core of Freud's conceptualization of the uncanny.

For Linda Dryden (2003, p. 17-18), the double encodes an anxiety about otherness and points to the possibility of a dual self, embodying "oppositions like day and night, light and dark, upper worlds and lower worlds, wealth and poverty, beauty and ugliness". More than a psychological condition, duality "is a factor of late nineteenth-century metropolitan life that can be identified in the physical geography of the city as well as in the individual existence". In late nineteenthcentury fantastic literature, then, the double is rearticulated within a moral and social discourse, especially if we take into account that the Gothic revival in this period involved a transposition of a Gothic atmosphere from exotic and remote locations to the urban centers, in an attempt to work through the new experiences offered by life in the big cities, with their contrasts, fragmentation, and countless possibilities. Therefore, it is not surprising that critics such as Paul Coates associate the emergence of the double in nineteenth-century literature to the experience of modernity itself. For Coates (1988, p. 2-5), the encounter with the Other in the process of colonization already entails a kind of doubling as the European colonizer projects his own self over the natives he tries to subjugate; the split between written language and oral speech, which occurs with the widespread dissemination of the press, creates similar doublings, just as the reproduction of images through photography, film and television helps foster a sense of duplication. According to Coates $(1988$, p. 2), the emergence of the double in literature occurs simultaneously with the 
invention of machines sophisticated enough to behave like humans, citing Hoffman's work as an early example of the imbrication of modern technology with the figure of the double. Marina Warner $(2007$, p. 165, 168) likewise connects the double with the development of technologies of reproduction.

Despite its importance in the fantastic, the motif of the double has permeated other genres (FONSECA, 2007, p. 190). Given its connection with modernity and with the dissemination of technologies of reproduction, it is not surprising that this motif would have a strong presence in science fiction, a genre that Linda Dryden $(2003$, p. 2$)$ sees as a development of the Gothic in the late nineteenth-century. The science-fictional double assumes multiple forms, including the clone, the android, the other self from an alternate reality, duplicates created through time travel, the shape-shifting alien, and digital copies of the mind. In science fiction, the double is divested of its supernatural elements, remaining only as a product of direct technological intervention.

In a short text that offers a brief theorization on the short story, but which actually focuses mainly on fantastic tales, Julio Cortázar describes his own sense of unreality when confronted with a woman who insisted he could not possibly be the person he alleged to be, since the real Julio Cortázar was an old man who had never left Buenos Aires and who was a close friend of one of her relatives. Since by that time Cortázar had been living in Paris for twelve years, this experience made him feel like a specter haunting or being haunted by his counterpart abroad (CORTÁZAR, 1993, p. 148). This is a striking instance of the eruption of the uncanny in everyday life, something that Freud (2010) also discusses in his essay; but it is also a powerful demonstration of how the figure of the double is closely connected to the issue of personal identity - as Dryden (2003, p. 39) points out, the "literature of duality is, at its most obvious level, a literature about identity, or even lack of identity". This may go a long way to explain the frequent presence of representations of the double in science fiction, since this is a genre largely concerned with the notion of otherness and the nature of the human.

For Fredric Jameson (2007, p. 61), science fiction is essentially historical; indeed, he argues that it is the sense of history present in science fiction that most sharply distinguishes 
it from fantasy. In fact, historicity is closely connected to Darko Suvin's definition of the kind of estrangement that he sees at the core of science fiction, an oscillation between the author's empirical reality and the alternate reality represented in the narrative. In establishing a dialectic relationship between these two realities, the reader is able to see his own context from a more distanced perspective, perceiving it as a specific historical time, shaped by specific social and human relations (SUVIN, 2010, p. 76). This emphasis on historicity means that science fiction tends to see identity not only as changeable over time, but also as being influenced, if not determined, by broader social and historical contexts. In the case of dystopian science fiction, which focuses on the troubled relationship between individual and society, the issue of identity acquires a special urgency.

It is not surprising, then, that the figure of the double appears with a certain frequency in dystopian fiction, especially in those narratives in which the science fictional exploration of technological development is more pronounced. This is the case, for instance, of narratives involving cloning, such as Kazuo Ishiguro's novel Never Let Me Go, or the duplication of minds through electronic means, as in many episodes of the television series Black Mirror. In these narratives, the double emerges as an emblem not only for the fractured self of modernity, or for the conflicting components of the psyche, but also for social and political conflicts typical of the contemporary stage of global capitalism. In that sense, it represents a rearticulation of its earlier manifestations in nineteenth-century Gothic fiction. My aim in this article is to trace some of the meanings the double acquires in this new articulation by briefly analyzing the ways it is represented in contemporary dystopian fiction and in science fictional narratives with strong dystopian overtones, ranging from short stories to film. I hope to show how traditional meanings of the double are reworked in a new context, and how the traditional relationship between double and original is transformed in contemporary fiction. I am particularly interested in investigating how the uncanny is reworked in a genre whose literary strategies are in many ways different from those of fantastic fiction, with which this category is more frequently associated. 


\section{The dark self}

In his essay on the uncanny, Freud quotes Otto Rank in order to argue that the double originally appears in primitive societies as a guarantee against death. According to Rank, primitive narcissism leads to the creation of an image of the immortal soul as an entity closely similar to the physical self, in a reaction against its ineluctable destruction: "The idea of death, therefore, is denied by a duplication of the self incorporated in the shadow or in the reflected image". Nevertheless, the original threat reappears in the figure of the double itself, which becomes a messenger of death or a persecuting agent (RANK, 1971, p. 83, 85-86). It is precisely as a consequence of the wish to prevent death that the double emerges in Greg Egan's short story "Learning to Be Me", first published in 1990 in Interzone magazine.

In this short story, a device is implanted in everyone's brain at birth in order to mimic the connections among the neurons and their activation, while recording every thought, memory and sensorial input of each individual, thus creating a perfect reproduction of the original mind. This mechanism, called the jewel, is periodically updated so as to avoid any discrepancy between the organic brain and its artificial counterpart. When the organic brain begins to deteriorate around the age of thirty, it is removed and substituted by the artificial mind, which would then live forever in a succession of bodies cloned from the original individual. Although this removal is optional, social pressure, education and a consistent official campaign ensure that few people choose to retain their organic brain. "Learning to Be $\mathrm{Me}^{\text {", }}$ then, offers an example of Foucault's (2006, p. 159-166) notion of biopolitics carried to the extreme, since it presents a society in which the "machineman" has become a literal reality, turning death into an inconvenience to be corrected by a more advanced design of the human, a problem to be rationally solved through the use of technology in the name of a higher efficiency.

A sense of the uncanny can already be felt in the first line of the short story: "I was six years old when my parents told me that there was a small, dark jewel inside my skull, learning to be me" (EGAN, 1991, p. 448). Since at this point the reader cannot know what this "jewel" actually is, the device seems 
to refer to the self, which appears as something "dark", secret, private, maybe dangerous (it seems parasitical), and, at the same time, precious. Identity becomes fractured and uncanny, because the individual self, which is supposed to be familiar, is presented as an external intrusion within the mind, intimating that the self is from its inception an Other - a basic feature of the double (DRYDEN, 2003, p. 9; COATES, 1988, p. 2-5; WARNER, 2007 , p. 160-166). In any case, it becomes obvious that the self is a product of growth: it is necessary to learn to be "me". But, at the same time that the self is a construction, it remains mysterious and undefinable. While debating whether to go through the operation that would remove his organic brain, the protagonist reasserts an image of the human as something indeterminable: "At first, I declared that within these errors [possible discrepancies between the artificial neural net and the organic brain], however small, lay the difference between brain and jewel, between human and machine, between love and its imitation" (EGAN, 1991, p. 451). This points to a metaphysical conception of the human, to the idea of an essence that cannot be fully comprehended, much less mechanically reproduced.

But, while identity is connected to secrecy in "Learning to Be $\mathrm{Me}^{\prime \prime}$, it is also connected to imprisonment. The first image of the "jewel" as a dark and mysterious object imbedded in the protagonist's brain already points in that direction, and this is confirmed when it acquires self-conscience at a later stage in the narrative. This happens when it feels a trivial desire that diverges from its organic body: while shopping online, it wants to buy some apples, but its body buys pineapples (EGAN, 1991, p. 455). At this point, the "jewel" has the sensation of having lost control over its own body; it can still feel the input from its senses, but it has lost the ability to speak to others or to dictate the movements of the body, which remains under the influence of the organic brain. This moment of radical fissure also marks a shift in the reader's expectations, for it immediately becomes clear that the real narrator of the story was never the organic self, but its artificial counterpart. In a reversal of the traditional trope of the double, we have access not to the conscience of the original self, but to that of its copy. As a consequence, both the body and the two consciences that inhabit it become uncanny, at the same time familiar and strange, and the experience of identity is marked by this uncanniness: "(...) the 
perfect familiarity of the signals from my body only made the experience more horribly wrong" (EGAN, 1991, p. 456).

Through its isolation, the artificial conscience becomes aware of its own being, and, like the Cartesian subject, it seems to establish its right to exist through this awareness. As in Paul Ricœur's formulation (2014), it acquires an independent identity through its ability to refer its thoughts and attitudes to itself, to take responsibility for them, to see itself as a constant point of reference while incorporating the changes brought by the passage of time. From this point of view, it necessarily sees its adjustment to the pattern of the organic brain as a form of murder, since this would erase its own memories and thoughts as far as they deviate from the original, destroying the personal experience that constitutes its identity. Nevertheless, it is forced to conform to this adjustment at least in appearance in order to guarantee its continuing existence: "I must conform - of my own free will. I must choose to make myself appear identical to that which they would force me to become" (EGAN, 1991, p. 457 , author's emphasis). The quandary faced by the narrator of "Learning to Be $\mathrm{Me}^{\prime}$ encapsulates the dilemma involved in the insertion of the individual in modern bourgeois society. For if in a liberal society individuals are supposed to be free, and the pursuit of personal happiness is a core value, how is it possible to maintain this while assuring the integration of the individual into the larger social body? The answer seems to be a voluntary conformity to the law, to dominant morality and to widespread social practices. A host of critical thinkers, from Nietzsche to Freud, Adorno and Foucault, have shown the shortcomings and the tensions inherent in this solution, in a long debate that, according to M. Keith Booker (1994, p. 1-23), paves the way for the rise of dystopian fiction and offers its theoretical background. If, as Tom Moylan (2000, p. 181) argues, "every dystopian narrative engages in an aesthetic/ epistemological encounter with its historical conjuncture", it is necessary to take this conjuncture in a broader sense as well, and see in dystopia a way to interrogate modernity itself.

It is at this point, when the conflict between an individual conscience and a larger social structure that demands its destruction is more dramatically represented in the narrative, that the dystopian character of "Learning to Be Me" becomes clearer. As the operation to remove the organic brain finally 
occurs, the artificial conscience finds that its discrepancies in relation to the original pattern have not been corrected and that its integrity has been preserved, while its organic counterpart has been destroyed. The narrator then realizes that there was a vast conspiracy to murder all organic brains in order to replace them with the artificial neural nets. Discrepancies between the two were unavoidable, since the organic brain deteriorates while the artificial neural net perpetually retains the same performance level: "The jewel's imitation of the brain leaves out - deliberately - the fact that real neurons die" (EGAN, 1991, p. 459; author's emphasis). The double carries to the letter its function of excising death, at the same time that it becomes a powerful reminder of the inevitability of death for the original self. The institutions responsible for the operation that replaces the organic brain - the institutions that carry out the social program of biopolitical control - discreetly hide from their costumers the discrepancies that would endanger this program, leading them to opt for the removal of their original brain under the illusion that the neural net is identical to it. Social control asserts itself under the guise of a free choice that proves to be biased, since it is based on incomplete information.

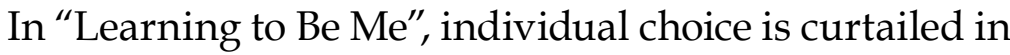
favor of order, since disgruntled users of the jewel who might learn that it is incapable of perfectly emulating the organic brain might denounce the imperfections in the program, thus threatening the whole social order. Protests are therefore silenced before they can actually be voiced. Society emerges as authoritarian and murderous, favoring the mechanical efficiency of the jewel over the imperfections of the organic brain. The literary device of the double functions here as a way to inscribe these social conflicts within the individual, and they become part of the whole process of identity-construction. As a consequence, identity is necessarily fragmented, for it is constituted on the basis of the fissure between individual and society. The sense of the uncanny that is pervasive in this narrative points to the contradictions inherent in this process. It reveals, through the threat of (and to) the double, the manipulation of the individual that remains hidden in the social organization, acting as a sort of return of the repressed as in Freud's (2010) articulation of the uncanny, but on a broader social scale. At the same time, identity itself becomes 
uncanny, since it is connected to secrecy and to the unseen, remaining strange and familiar at the same time. Conflicting images of the self, therefore, emerge in the narrative, without reaching a stable resolution. The existence of a virtual self seems to subscribe to the assumption, very common in science fiction, that the mind is independent from the body, and that identity is primarily connected to the mind - an assumption that Ricœur (2014, p. 139, 157-159) rejects by insisting that identity is also ground on the body. The latter view, however, is reinstated when it is shown that the difference between the artificial conscience and its original lies precisely on their physical support (the incorruptible neural net and the organic brain, respectively). Nevertheless, the possibility that identity is essentially programmable remains, at the same time that a more traditional notion of the self as something secret, private and ultimately indefinable is sustained in the gap between the double and its original, in the mystery of their choices (why would one choose pineapples over apples at a specific point?), in the unsubstantial nature of their difference, though, paradoxically, they still share the same identity.

\section{An extreme case of self-control}

A more blatantly negative view of a society in which human relations are largely defined by technology can be found in the television series Black Mirror. As in "Learning to Be Me", society here is essentially authoritarian, but it is impossible to point to a single instance of authority. As in Foucault's formulation of the structure of power in bourgeois societies (1990, p. 94-97), power in Black Mirror is a network that permeates the social body as a whole, taking shape in the different interactions that constitute social relations; it is exercised by distinct individuals in distinct situations, in a series of attempts to achieve control over others and over one's own self. This emphasis on power and mutual control also leads to a representation of society as largely selfish and narcissistic, aspects that become particularly pronounced in White Christmas, the last episode in the second season of the series, originally broadcasted as a Christmas special on 16 December 2014. Through the framing device of two men apparently strangers - who are trapped in an isolated cabin 
during a snow storm and talk about their past experiences to each other, the episode develops three loosely connected stories, all of them involving technologically created doubles to a different degree. In the second of these stories, narcissism turns into a sadomasochistic nightmare as a woman tortures and explores herself in the figure of her double.

As in "Learning to Be $\mathrm{Me}^{\text {", }}$ the protagonist has a device implanted in her head in order to faithfully reproduce her mind, not in view of achieving eternal life, but with the more prosaic aim of creating an artificial intelligence that would manage her house and her social appointments. Being a faithful copy of herself, this artificial intelligence would anticipate all her needs and organize her immediate environment according to her tastes. Greta, the protagonist of this sub-plot of White Christmas, envelops herself in the protective cocoon of her own mind, leading a life she believes to be shaped according to her own exacting specifications. The concretization of this narcissistic dream, however, comes at the price of objectifying her own self. The double here is not the physical manifestation of a moral conscience that haunts a criminal subject (COATES, 1988, p. 34). It is rather an object of desire, although a desire that is not exactly eroticized. The effects of mirroring created by the images in the episode have more to do with control than with self-admiration, and even less with self-reflection. Greta's double is able to watch her original through the multitude of cameras installed in the house, but this voyeurism is imposed on her by the demands of her job as caretaker. The double herself, on the other hand, is caught between occultation and extreme visibility. It is imbued with the illusion of a physical body (also an exact copy of the original) which inhabits a white, empty space without any apparent delimitation, and furnished only with a chair and the console where she is supposed to do her work. In this wide and featureless space she has nowhere to hide and remains absolutely visible. On the other hand, the double and the virtual reality she inhabits are stored within an electronic device in the shape of an egg. They are perfectly enclosed within an opaque object whose reduced size is constantly stressed in its visual representation among the other objects in Greta's kitchen, reinforcing the idea of the double's imprisonment. 
Greta, however, never sees the image of her own double. She delegates the task of dealing with her to the technician who is responsible for training the newly created artificial intelligence. Since at first the double is unaware that it is actually a copy of Greta's mind, she refuses to perform the work assigned to her, and only submits after undergoing the torture of boredom and isolation. The technician is able to speed up the passage of time in the virtual reality the double inhabits, so that weeks and then months go by in the double's perception, while only a few seconds have elapsed in real time. Cut out from the outside world, and with absolutely nothing to do, the double finally breaks down and agrees to work as Greta's personal organizer, since this is the only form of contact with something outside the emptiness of her virtual environment left to her, and also the only activity allowed to her. The egg, then, functions as a perverse symbol for the isolated, monadic notion of the modern individual, whose privacy and secrecy, still evoked by the opaque surface of the egg, is nevertheless violated by the total visibility of the double. This visibility not only acts as a form of absolute control, but also establishes a clear hierarchy, as the image of the double appears tiny in relation to the huge face of the technician on the screen that comprises a whole wall in the double's environment. The double's visibility also marks her fragility, since it is a sign of her exposure, and it heightens the spectacle of her suffering for the viewer. It becomes clear, then, that the double is indeed the repository of undesirable aspects of the self (RANK, 1971, p. 79$80)$, but not in terms of representing the criminal tendencies of the id or the moral influence of the superego. Here, the double is the receptacle of this very fragility, of Greta's insecurities and confusion. After having the double excised from her, Greta seems cool and self-assured, but in the opening sequence of her story, she is shown in a hospital bed, waiting to extract the device in her skull that records her own mind, and afraid of complaining to the nurse that the toast she has brought her is overdone. In this way, the double opens up the possibility of acquiring a new self, of becoming someone different while remaining the same, a possibility that Marina Warner (2007, p. 165) associates with modern advertising campaigns. Greta's double is indeed a merchandise, another gadget in her kitchen, 
and is consistently treated as such. The self becomes an object of acquisition, and narcissistic desire turns into consumerism.

The uncanniness of the double in White Christmas points once again to social contradictions: it is recognizable as an object of consumption while being forcefully presented as a rational being who deserves to be treated with dignity. For Kant, the respect for the dignity of all rational beings is at the roots of morality. In his view, all objects that can be used as a means to an end outside themselves have a price, based on their utility or agreeableness; any rational being, on the other hand, is imbued with an autonomous will and therefore is an end in itself. "What has a price can be replaced by something else as its equivalent, what on the other hand is raised above all price and therefore admits of no equivalent has a dignity" (KANT, 1997, p. 42). Morality offers the condition under which a rational being can retain this dignity. Hence Kant's formulation of the practical imperative that should guide moral actions: "So act that you use humanity, whether in your own person or in the person of any other, always at the same time as an end, never merely as a means" (KANT, 1997, p. 38). The treatment of the double in White Christmas infringes this imperative on two counts. Seen as an object, the double becomes an Other whose condition as an autonomous rational being is denied, and who is treated merely as a means. However, since the double is also a reflection of the original, her instrumental use extends to Greta's own self. Working largely on Kant's moral imperative, Ricœur (2014, p. 210-214) argues that it is through solicitude that one recognizes in the other a being capable of self-esteem, with their own projects, judgement and personal preferences - someone who is irreplaceable. For Ricœur, it is through this realization that one manages to project these same traits over to one's self, and to finally see oneself as equally irreplaceable and valuable as a human being. In objectifying her double, Greta objectifies herself and suppresses her own humanity in the service of a narcissistic ideal of the self.

This ideal does not involve the search for higher moral qualities, but rather the search for a higher efficiency: Greta's insecurities are left behind so that she will always function at her best. This perfectly controlled self is reflected in the perfectly controlled work of the double. For the double also fulfills the fantasy of the perfect worker, one who has no 
need of sleep and who literally has nothing to do other than her job. As Coates $(1988$, p. 2$)$ argues, the double appears here as a projection of the self over a colonized Other, who is no longer the native from the period of European expansion, but the workforce of late capitalism. The motif of the double is employed in White Christmas as an indictment of dehumanizing work relations that privilege maximum productivity at the expense of the worker's autonomy, and that tends to treat employees as objects that can be readily discarded or replaced. But in this case, it is also the self that is colonized in the name of efficiency. As pointed out above, after the creation of her double, Greta seems cold and distant, almost inhuman in her apparent perfection, as sleek as the objects that furnish her impeccable home. The whiteness of the egg where her double is stored suffuses all the environments displayed in this section of White Christmas, including the virtual reality inhabited by the double, the interior of Greta's house and even her dress. While at first the image of the egg seems to hold its traditional meaning of the promise of new life, its color points rather to the idea of sterility, especially as it first appears in connection to the hospital. The messiness of the human is relegated to the double (significantly dressed in black), the only one who displays unrestrained emotions during the process of her subjugation. The suffering of the double is clearly meant to incite a sense of moral condemnation from the viewer - a condemnation explicitly voiced by the character in the frame narrative of White Christmas who listens to this story and who sees in it a description of a form of slavery. The critique of social exploitation, and the anxiety concerning the dehumanizing influence of technology are then cast as a moral problem, as if the whole episode were a demonstration of the urgency of Kant's moral imperative.

\section{Mass production}

The question of morality has always been present in the literary motif of the double. Freud (2010, p. 352-353) argues that, even after primitive narcissism has been overcome, the figure of the double can remain as the result of the creation of a separate aspect of the self which is responsible for self-criticism and self-observation, and which he associates with our moral 
conscience. In dystopian science fiction, however, the question of morality tends to implicitly address Kant's imperative, rather than concentrate on the moral conflicts within the individual. In Aldous Huxley's Brave New World, the Savage is horrified to see the same face on dozens of workers from a lower caste, the product of a process of artificial insemination that manages to grow a large number of embryos from a single egg: "[he] knew what he saw - [...] the nightmare of swarming indistinguishable sameness" (HUXLEY, 2006, p. 209). For Coates (1988, p. 2-3), the "genetic creation of these identical hordes [in Brave New World] translates into actuality the nationalistic ideologies of fascism: the nation as a hall of mirrors, endlessly prolonging collective narcissism"; but they are also a manifestation of the double as a concretization of the "fear of the feasibility of the self's total reification by science". In dystopian fiction, the issues raised by Kant's moral principle are articulated in association with the dynamics of power and the capitalist mode of production.

Although they are not technically clones, the massproduced people in Brave New World offer an early indication of the ways the figure of the clone would be developed in later dystopian science fiction. In these narratives, it is not the relationship between the double and its original that is privileged, but rather the potentially endless reproduction of the clone and the threat of the objectification of the human this represents. This threat is dramatically represented in Kazuo Ishiguro's novel Never Let Me Go, in which the British government produces clones in a more or less industrial scale with the sole purpose of furnishing material for organ transplants. As in the earliest manifestations of the double, these clones offer the possibility of the extension of life for those who benefit from them, but they are also a powerful reminder of death, which looms large in Ishiguro's novel, most of whose characters are condemned to die after donating their organs in successive operations. Reduced to a repository of organs, these clones are seen as mere objects, as means to an end whose humanity is denied. Much of the novel focuses on Kathy H.'s reminiscences of Hailsham, the school where she was raised together with other clones and her relationship with Ruth and Tommy, two close child hood friends. The later part of the novel revolves around her efforts to get herself and Tommy temporarily suspended from the organ-donation program, so 
that they could stay together for some time. These efforts are largely based on the evidence of the artwork she and Tommy produced in Hailsham, and which was collected by the former school director in an attempt to prove to the government that the clones had a "soul" - or, to put it Kantian terms, that they were rational beings with an autonomous will whose dignity ought to be respected. This attempt - a pipe dream to begin with, given society's reluctance to see the clones as human predictably fails, and Tommy dies after his last organ donation. The novel closes with a powerful image of loss:

[...] I was thinking about the rubbish, the flapping plastic in the branches, the shore-line of odd stuff caught along the fencing, and I half-closed my eyes and imagined this was the spot where everything I'd ever lost since my childhood had washed up, and I was now standing here in front of it [...]. (ISHIGURO, 2005, p. 287)

The "rubbish" Kathy sees is of course an image of her own memories and of herself, and it is also a representation of her social position. In Never Let Me Go, clones are doubly marginalized, first because they are denied their humanity, and second because they know they have been cloned from the so-called "garbage" of society: "We're modelled from trash. Junkies, prostitutes, winos, tramps. [...] If you want to look for possibles [the clones' originals] [...] then you look in the gutter. You look in rubbish bins. Look down the toilet, that's where you'll find where we all came from'"' (ISHIGURO, 2005, p. 166, author's emphasis). This is Ruth's explosive reaction when she realizes that an office worker, spotted by one of her friends as the person from whom she could have been cloned, did not look at all like her. Ruth's search for her "possible" is an expression of her attempt to create for herself a significant life, in a projection of what would constitute a "real" person, who she imagines comfortably working at an office and pursuing her own purposes and desires. The fact that this search is never satisfied - the original is never found - turns the clone into a concrete representation of Baudrillard's simulacrum (1991, p. 7-9), a copy or an image without referent, a representation, therefore, of the post-modern condition. The longing for a respectable job, possible only at the level of fantasy and projection, points to the clone once again as a means to discuss the precariousness of work and the social insertion of the 
individual, shown here as exploited and deprived of rights - a common anxiety in neoliberal societies.

Similar anxieties are present in the film Moon (2009), directed by Duncan Jones. Here, the single employee of a lunar mining operation wakes up after an accident to find a copy of himself in his place. It is not long before the two incarnations of the same character reach the conclusion that they are clones, the most recent in an apparently limitless series of versions of themselves that succeed each other as employees at the station, for each clone has a life span of only three years. They are a cheap and replaceable work force, an efficient way to cut costs, since it is less expensive to use a succession of clones activated on site than to ship new employees to the moon.

To this new example of the exploitation of labor is added the crisis caused by the scission of identity. Predictably, the relationship between the two clones is hostile in the beginning, in a contemporary rendition of the traditional theme of the conflicted self. Although the clones are a perfect physical copy of each other, they have distinct personalities - not because of a defect in their creation, but because they are like two versions of the same person in different moments: one of them has just been activated, while the other is reaching the end of his threeyear lifespan, having accumulated an experience of forced introspection that the first one lacks. As in the late nineteenthcentury Gothic narratives discussed by Linda Dryden (2003, p. 41), the double appears as the image of an altered self, of a fluid identity in constant transformation. If, on the one hand, this fluidity - which Bauman associates with a contemporary model of identity - offers the beguiling prospect of a constant opening up of new possibilities, on the other hand it can also be a source of anxiety, due to a loss of references and stability which generates a perpetual state of uncertainty (BAUMAN, 2010, p. 53-90). In Moon, the fluidity and fragmentation of the self are presented as a problem through the figure of the clone. The film raises the possibility that the self does not own its identity, that it is disconnected from its memory and its past, which belong to another that remains out of reach - another original that is never found. Memory constitutes itself as a series of false recollections, at least in the sense that they have been transplanted from this lost original, and there is 
no guarantee that at least part of them has not been invented. The physical traces of these recollections are photographs and videos that could easily have been created or selected by those who have programmed the clones, serving as the basis for an idealization of the past that may not correspond to the truth. In any case, a fissure is established between the present self and its past; the self, therefore, is provisional and frail.

In Moon and Never Let Me Go, this fragility finds a concrete representation in the body of the clone, who is condemned to a short life, as the replicants in Blade Runner. In Moon, in particular, we watch a spectacular degradation of the clone's body as it approaches its expiration date, turning into a suffering body in dissolution. For Keith Booker (1994, p. 49-50), the strength of dystopian narratives lies in representing the suffering of specific fictional characters, which offers a parallel to the suffering of real people under adverse social conditions, going beyond the allegorical account of political structures or the theoretical cogitation of cultural critics. The body of the clone acts as a locus where the social contradictions outlined in the film find their most dramatic and concise expression, not only because of the graphic representation of its suffering, but also because it is both engendered and destroyed as part of a rampant capitalist logic of production. Furthermore, the negative aspects of a fluid identity find a concrete representation in the blood and other fluids this body secretes in its process of disintegration.

The physical deterioration of the clone in Moon and its instrumental use in Never Let Me Go call attention to the materiality of the human, raising the possibility that the latter is nothing more than a body with no transcendence - an anxiety that Kelly Huxley detects in late nineteenth-century Gothic narratives. For Huxley (2004, p. 3-7), the Gothic resurfaces periodically as a genre in moments of cultural crisis - in the case of the late nineteenth and early twentieth centuries, this crisis is related to the influence of science in creating a more empiricist view of the human. The rearticulation of the double in the narratives that I have been discussing, which owes so much to the Gothic tradition, suggests that we are facing a similar moment of cultural crisis in which the category of the human is also being put into question. 
While clones are reduced to a body, their social insertion reduces them to a function: being a worker in Moon, being a repository for transplant organs in Never Let Me Go. The clone longs, then, to create transcendence where there is none, and to establish his or her own humanity in a social structure that denies it. At the same time, the fragility of the clones, the spectacle of their suffering, puts them in the position of a victim that commands the compassion of the reader or spectator. In a way, clones are an ideal object of sympathy: precisely because they are artificially created, they do not have their own history, which brings them closer to the image of the child and confers them an aura of primordial innocence. Created by society, but without actually being one of its members, the clone seems free from the interests that condition fully socialized human beings.

The figure of the clone - and, in broader terms, that of the double - in the narratives I have been discussing points to the danger of the instrumental use of the human in contemporary society, of its reduction to a body to be administered and a social or economic function to be fulfilled. It also points to a crisis in the enlightened notion of a unique and coherent individual, whose identity, however dynamic, remains relatively stable through time. The jewel in "Learning to Be $\mathrm{Me}^{\prime}$ and the egg where the artificial intelligence is stored in White Christmas are obvious representations of imprisonment; but it is through this imprisonment that the doubles in both narratives become conscious of their existence as an autonomous, self-aware being. In White Christmas, an important part of the violence committed against the double is the infringement of her privacy. In the narratives discussed here, the uncanniness of the double points to the tensions of an oppressive social order, but it is also a sign of the inscrutable mystery of the individual. The double ceases to be a monster, as in its earlier incarnations, to become the victim of a monstrous organization. The shock of its subjection and exploitation only makes sense if Kant's imperative to treat all rational beings as an end in themselves, and never merely as a means, is implicitly held to be valid. These dystopian narratives still evince the desire for a humanist subject, capable of feeling and self-awareness, imbued with an identity that, although constructed with much effort, points to a secret essence beyond any definition or control. 


\section{BIBLIOGRAPHY}

BAUDRILLARD, J. Simulacros e simulação. Trans. by Maria João da Costa Pereira. Lisboa: Relógio d'Água, 1991.

BAUMAN, Z. Liquid Modernity. Cambridge (UK); Malden (MA): Polity, 2010.

BOOKER, M. K. The Dystopian Impulse in Modern Literature: Fiction as Social Criticism. Westport (CT); London: Greenwood Press, 1994.

COATES, P. The Double and the Other: Identity as Ideology in Post-Romantic Fiction. Basingstoke (UK); New York: MacMillan, 1988.

CORTÁZAR, J. Alguns aspectos do conto. In: . Valise de Cronópio. Trans. by Davi Arrigucci and João Alexandre Barbosa. São Paulo: Perspectiva, 1993. p. 147-163.

DRYDEN, L. The Modern Gothic and Literary Doubles: Stevenson, Wilde and Wells. Basingstoke (UK); New York: Palgrave MacMillan, 2003.

EGAN, G. Learning to Be Me. In: DOZOIS, G. (Ed.). The Year's Best Science Fiction: Eighth Annual Collection. New York: St. Martin's Press, 1991. p. 447-460.

FONSECA, T. The Doppelgänger. In: JOSHI, S. T. (Ed.). Icons of Horror and the Supernatural: An Encyclopedia of Our Worst Nightmares. Vol. 1. Westport (CT); London: Greenwood, 2007. p. 187-213.

FOUCAULT, M. The History of Sexuality, Volume 1: An Introduction. Trans. by Robert Hurley. New York: Vintage, 1990.

Surveiller et punir: naissance de la prison. Paris: Gallimard, 2006. 
FREUD, S. O inquietante. In: Obras completas, vol. 14: História de uma neurose infantil ("O homem dos lobos"), Além do princípio do prazer e outros textos (1917-1920). Trans. by Paulo César de Souza. São Paulo: Companhia das Letras, 2010. p. 328-376.

HUXLEY, A. Brave New World. Harper Perennial Modern Classics. New York: HarperCollins, 2006.

HUXLEY, K. The Gothic Body: Sexuality, Materialism, and Degeneration at the Fin de Siècle. Cambridge (UK): Cambridge UP, 2004.

ISHIGURO, K. Never Let Me Go. New York: Alfred A. Knopf, 2005.

JAMESON, F. Archaeologies of the Future: The Desire Called Utopia and Other Science Fictions. $2^{\text {nd }}$ ed. London; New York: Verso, 2007.

KANT, I. Groundwork of the Metaphysics of Morals. Trans. and ed. by Mary Gregor. Cambridge (UK): Cambridge UP, 1997.

MOON. Directed by Duncan Jones. Produced by Trevor Beattie, Nicky Bentham, Stuart Fenegan et al. Script by Duncan Jones and Nathan Parker. UK: Liberty Films UK, Xingu Films, Limelight Fund, Lunar Industries, 2009. DVD (97min), sound, color, subtitled.

MOYLAN, T. Scraps of the Untainted Sky: Science Fiction, Utopia, Dystopia. Boulder (CO); Oxford: Westerview Press, 2000.

RANK, O. The Double: A Psychoanalytic Study. Trans. and ed. by Harry Tucker, Jr. Chapel Hill (NC): The U. of North Carolina P., 1971.

RICCEUR, P. O si-mesmo como outro. Trans. by Ivone C. Benedetti. São Paulo: WMF Martins Fontes, 2014.

SUVIN, D. Science Fiction and the Novum (1977). In:

Defined by a Hollow: Essays on Utopia, Science Fiction and Political Epistemology. Oxford; Bern: Peter Lang, 2010. p. 67-92. 
WARNER, M. Doubling. In: Fantastic Metamorphoses, Other Worlds: Ways of Telling the Self. Oxford: Oxford UP, 2007. p. 161-203.

WHITE CHRISTMAS. Black Mirror, season 2, episode 4. Directed by Carl Tibbetts. Produced by Charlie Brooker, Annabel Jones, Kathy Nettleship and Barney Reisz. Script by Charlie Brooker. United Kingdom, 2014. Streaming (73min), sound, color, subtitled.

WOLFREYS, J. Victorian Hauntings: Spectrality, Gothic, the Uncanny and Literature. Basingstoke (UK); New York: Palgrave, 2002. 


\section{Resumo}

Humanidade precária: o duplo na ficção científica distópica

O duplo é um elemento comum na literatura fantástica e desempenha um papel importante na retomada do gótico no final do século XIX. Ele questiona a noção de uma identidade coesa ao propor a ideia de um "eu" fragmentado que é ao mesmo tempo familiar e assustadoramente outro. Por outro lado, o duplo também é uma maneira de representar as tensões da vida nos grandes centros urbanos. Apesar de ser costumeiramente associado ao fantástico, o motivo do duplo se espalhou para outros gêneros, incluindo a ficção científica, gênero também preocupado com a investigação da identidade e da natureza do humano. Oobjetivo deste artigo é discutir a representação do duplo na ficção científica contemporânea, mais especificamente na sua modalidade distópica, onde a questão da identidade adquire uma relevância especial, uma vez que a distopia tem como foco a relação atribulada entre indivíduo e sociedade. Obras como o conto "Learning to Be Me", de Greg Egan; White Chistmas, episódio da série de televisão Black Mirror; o romance Never Let Me Go, de Kazuo Ishiguro; e o filme Moon, dirigido por Duncan Jones, serão brevemente analisados a fim de rastrear as maneiras como a figuro do duplo é rearticulada na ficção científica distópica como um meio de trabalhar novas inquietações a respeito da identidade pessoal e da posição do indivíduo na sociedade.

Palavras-chave: identidade; o "eu"; duplo; clone; sociedade contemporânea. 